'Companions',' The Nation. January 16, 2015.

3 Michael Hardt, "Affective Labor," boundary 2, 26.2 (1999): 96. Hardt quotes Dorothy Smith, The Everyday World as Problematic: A Feminist Sociology (Boston: Northeastern University Press: 1987), 78-88.

\author{
Zach Schwartz-Weinstein \\ New York University
}

\title{
Christopher M. White, A Global History of the Developing World (New York: Routledge, 2014). 275 pp. $\$ 44.95$ Paperback.
}

In this ambitious book, Christopher M. White has aimed for a short, but wideranging, history of the "developing world." Written in a style agreeable to a general readership, White is specifically concerned with speaking to undergraduate students, at times writing as though he is directly in front of them giving a lecture. Coming in at 275 pages, Global History joins a flurry of recent works seemingly aimed at capturing the first year undergraduate textbook market by offering shorter reads than the thousand page volumes common in years past.

White breaks the book into four parts: Imperialism, Nationalism, Globalization and Development. The first three parts, what he calls the "fundamentals of the modern history of the developing world"(1), are a chronological account beginning more or less with Columbus' initial encounters in the Americas in the late fifteenth century and ending around issues such as the Arab Spring protests in 2011. Undergraduate instructors will find that White's rendition of the past five hundred years touches upon many important signposts commonly found in recent world history textbooks. In each of the first three parts, chapters are organised around geographical areas: Latin America \& the Caribbean, Asia, and Africa, in other words, the "developing world" to which the book's title refers. Though he periodically gestures towards matters of religion, identity, culture and social life, for White the West's economic interests and concerns about international relations provide much of the fuel that drives the motor of his global history. "Development," the book's final part, focuses on scholars whose claims have either challenged imperialism, colonialism and capitalism in the "developing world," or have supported their expansion. White's book then ends by discussing ideas he believes offer some potential solutions to alleviate extreme poverty in the Third World.

White hopes students will use his historical narrative and the additional tools he provides (self-reflective questions, reading and film suggestions and a glossary) to challenge common assumptions they may have about the "developing world." "As college students," he writes, "you have a choice to make: do you prefer to make decisions based on preconceived notions or do you prefer to 
make informed decisions?" (3). I teach the type of students that White identifies as his core audience. My first year undergraduates in international development studies come with various motivations and ideas about the "developing world." I spend a lot of time teaching not only policies and practices but also the role of Western attitudes in helping shape global inequality. Thus, for those of us who believe that helping students become self-reflexive thinkers is a critical intervention, White's approach is welcome. He provides a wide range of interpretations and arguments that will generate insightful class discussions about the motivations and assumptions embodied in the discourses of progress and economic growth that dominate development and the contemporary aid industries.

While White clearly contributes to a better understanding of numerous complex and wide-ranging historical matters his book is not without problems. Critically, the four concepts that make up the book's historical periods are generally left undefined. How, for example, is imperialism different than globalization for White? Or, why was "the nation" such a powerful concept for anti-colonial movements in the twentieth century? These are questions undergraduate students tend to ask and I hoped White would have provided more direction on this front. Paying closer attention to cultural histories of development may have helped address some similarities and differences between each distinct period. Indeed, the treatment of culture occupies a confusing place within this book. At times, White makes thoughtful interventions into the relationship between culture and development. His penultimate chapter gives a strong critique of Westerners who use "cultural determinism" as a justification for intervention into the Global South (249-51). Yet such thoughtfulness is betrayed by glib and, at several points, frankly outrageous claims about culture in the "developing world." One memorable example is his claim that Africa is the "saddest region in the world" partly because of "factors inherent to Africa's culture" (emphasis mine, 149). These are profoundly troubling statements on numerous levels, especially from a scholar wanting to direct students away from ideas based upon "preconceived notions."

Writing a general text such as White's is a difficult undertaking. We are not trained as specialists in every topic that a general text requires us to cover. As White acknowledges several times, his investigation barely "scratches the surface." He provides many provocative and insightful points for discussion in very limited space. At other times, however, his brevity is a hindrance, leading to poorly argued points and insufficient coverage of complex histories. In the book's final section, "Development," the absence of important scholars on various sides of the development spectrum, from Edward Said and Arturo Escobar on the left to Dambisa Moyo on the right, is particularly notable. Moreover, as a scholar who wants students to engage with facts and not opinions, to claim, in reference to Cuba, that "in fact" universal health care, employment and education "are often not considered much of a benefit to people who can only aspire 
to the bare minimum"(83) reads more as the author's ideological agenda than it does an empirical assessment of everyday life on the streets of Havana. Arguments such as this, if they are not going to be explained in more detail, should be left out entirely. One wonders if the pressure to publish shorter and shorter volumes is partly to blame here.

With this said, paired with additional material that could help fill the gaps noted above, White's book offers instructors a thoughtful text to introducing students in world history or international development studies to a complex and multilayered set of histories that continue to shape current and future prospects for people living in the "developing world."

Scott Rutherford Queen's University

\section{Stephan D'Arcy, Languages of the Unbeard: Why Militant Protest is Good for Democracy (Toronto: Between the Lines, 2013). 232 pp. $\$ 24.95$ Paperback.}

In Languages of the Unheard, Stephen D'Arcy offers readers "a normative standard" that can assess when and how militant protest is good for democracy. One of the strongest aspects of Languages is the treatment of Martin Luther King as a political theorist. D'Arcy utilizes King to craft a four part definition of militancy: "grievance-motivated, adversarial, and confrontational collective action" (26); where adversarial indicates opposing positions that are no longer open to change through dialogue and confrontation is the act of "seek[ing] out direct conflict" (27). This sets up D'Arcy's basic argument. Militant protest is democratic because it can reopen dialogue and debate on issues that self-interested elites (bureaucratic and capitalist) would otherwise treat as settled.

In Languages, Democracy is defined as "public autonomy, that is, the self-governance of the people through inclusive, reason-guided public discussion" (4). D'Arcy places an emphasis on public autonomy to distinguish it from 'liberal' conceptions of democracy:

The demand for public autonomy is democratic in a much richer sense than mere public choice [ie. voting]. Public autonomy requires that the people dictate the terms of social co-operation based on broadly shared understanding of the common good and the requirements of justice, after a thorough process of inclusive wide-ranging discussion (23-24). Premised on the goal of achieving public autonomy as the ideal form of democracy, D'Arcy persuasively argues militancy is democratic if it meets four standards that, in the words of King, give "voice to the voiceless." These standards are:

opportunity principle - have a reasonable chance of creating new 